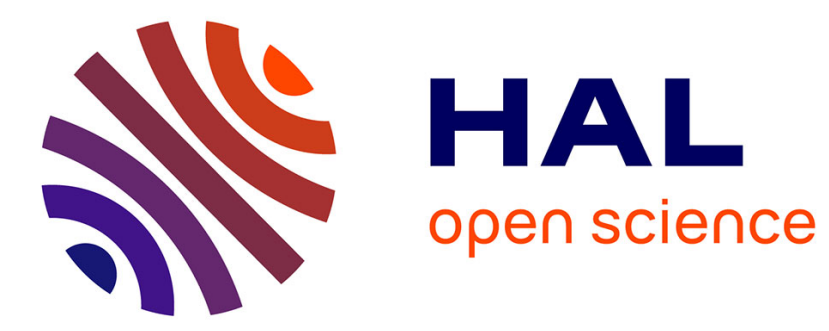

\title{
GCC Sovereign Wealth Funds: Why do they Take Control?
}

Jeanne Amar, Jean-Francois Carpantier, Christelle Lecourt

\section{To cite this version:}

Jeanne Amar, Jean-Francois Carpantier, Christelle Lecourt. GCC Sovereign Wealth Funds: Why do they Take Control?. 2018. halshs-01936882

\section{HAL Id: halshs-01936882 \\ https://shs.hal.science/halshs-01936882}

Preprint submitted on 27 Nov 2018

HAL is a multi-disciplinary open access archive for the deposit and dissemination of scientific research documents, whether they are published or not. The documents may come from teaching and research institutions in France or abroad, or from public or private research centers.
L'archive ouverte pluridisciplinaire HAL, est destinée au dépôt et à la diffusion de documents scientifiques de niveau recherche, publiés ou non, émanant des établissements d'enseignement et de recherche français ou étrangers, des laboratoires publics ou privés. 


\section{amse}

école d'économie d'aix-marseille

aix-marseille school of economics

\section{Working Papers / Documents de travail}

\section{GCC Sovereign Wealth Funds: Why do they Take Control?}

Jeanne Amar Jean-François Carpantier

Christelle Lecourt 


\title{
GCC Sovereign Wealth Funds: Why do they Take Control?
}

\author{
J. Amar* J.F. Carpantier ${ }^{\dagger}$ and C. Lecourt ${ }^{\ddagger}$
}

This version: November 2018

\begin{abstract}
In this paper we examine the investment strategy of sovereign wealth funds (SWFs) of the Gulf Cooperation Council (GCC) countries. GCC SWFs are considered as relatively opaque investors and strongly politicized, raising some concerns for perceived political and security risks. We investigate what are the drivers of majority crossborder equity acquisitions made by these institutional investors over the period 20062015. Using both Logit and ordered Logit models, we test if the usual determinants of SWFs investments still stand when we look at influential $(>10 \%)$ or majority (>50\%) acquisitions made by GCC SWFs. We find that GCC SWFs do not consider financial characteristics of the targeted firms when they acquire large cross-border stakes but rather the characteristics of the country (countries in the European union and/or countries with a high level of shareholders protection), suggesting that their motives may go beyond pure profit maximization. We also find that transparent funds are more likely to take influential or majority stakes and that they do so predominantly in non-strategic sectors. Overall, our results indicate that even if GCC SWFs do not seek only for financial returns, acquiring majority stakes is not a lever for GCC governments to get strategic interests in the target countries.
\end{abstract}

JEL classification: F310; F31; G15

Keywords: Sovereign Wealth Funds; Cross-border Majority Acquisitions; Ordered Logit model ; GCC.

${ }^{*}$ University of Nice Sophia Antipolis, GREDEG. jeanne.amar01@gmail.com.

${ }^{\dagger}$ Aix-Marseille University, Cergam EA 4225, jean-francois.carpantier@univ-amu.fr.

¥Aix-Marseille Univ., CNRS, EHESS, Centrale Marseille, AMSE. christelle.lecourt@univ-amu.fr. 


\section{Introduction}

Defined by the IMF (2004) as "government-owned investment funds set up for a variety a macroeconomic purposes" such as stabilisation, saving for future generations and investments in socio-economic projects, sovereign wealth funds (SWFs) have sharply grown over the last decade, with resources estimated to be USD 7.3 trillion in June 2017, thanks to high oil prices, financial globalisation and sustained global large imbalances. ${ }^{1}$ SWFs have recently attracted considerable public attention. While the size and rapid growth of SWFs suggest that they have become major players in the world, buying large stakes in companies and giving government's exposure to sectors they may otherwise be unable to achieve, their objectives and behavior are not well understood. In particular, the opaqueness surrounding their structure and activities is a major concern in host countries, as it is unclear whether SWFs behave like governments or institutional investors: "the prospect of significant investments by SWFs potentially giving foreign countries control over important parts of an investee country's economy has emerged as a political issue" (Greene and Yeager, 2008).

This is particularly the case of SWFs originating from the Gulf Cooperation Council (GCC) countries ${ }^{2}$, by which the amount accumulated has dramatically increased since 10 years due to the increasing prices of commodities such as oil and natural gas. SWFs of GCC countries manage around $40 \%$ of SWFs global assets. The SWFs of these countries are broadening their investment portfolios and focusing on achieving higher returns. Consequently, they have invested all over the world during the last decade with the bulk of them focused on developed countries and in particular Europe. It has become common news to hear that one of these GCC funds is in the process of buying, planning to buy or investing in a major institution in Western countries.

A revealing example is the full acquisition by Qatar Investment Authority (QIA) in 2011

\footnotetext{
${ }^{1}$ According to the Sovereign wealth Fund Institute, the assets managed by these funds were estimated to be USD 3,2 trillion in September 2007, which means that the size of these funds has more than doubled since the beginning of the financial crisis (source: www.swfinstitute.org).

${ }^{2}$ GCC member states are Bahrain, Kuwait, Oman, Qatar, Saudi Arabia and the United Arab Emirates. The United Arab Emirates are a federation of seven emirates, including Abu Dhabi, Dubai and Ras alKhaimah, which all have their own SWF.
} 
of the popular football club Paris St. Germain. The same SWF has played the part of deal-maker with the Glencore acquisition of Xstrata in 2013 and with Glencore again by buying stakes in Russian oil company Rosneft in December 2016. In June 2016, the Public Investment Fund (PIF) of Saudi Arabia has announced to have taken a USD 3.5 billion stake in the taxi company Uber, in order to diversify the economy of the country by investing in sectors less dependent on oil. These examples illustrate well the fact that the motives of GCC funds can be other than pure profit maximisation of the financial investment and reveal their capacity to take the control or to be able to influence companies involving the strategic national interests.

While there is an extensive literature that investigates the determinants of SWFs investment decisions (see Amar et al. (2018); Ciarlone and Miceli (2016); Knill et al. (2012); Kotter and Lel (2011); Megginson et al. (2013) among others) only few papers address the question of the determinants of cross-border majority purchases. Karolyi and Liao (2017) analyze cross-border majority acquisitions of government-led acquirers, Heaney et al. (2011) analyze the determinants of Temasek Holding's level of investment and Murtinu and Scalera (2016) show that SWFs are more likely to use investment vehicles when they take crossborder majority stakes. This is, however, a key question as it is clear that SWF activism, i.e. the acquisition of large or majority acquisitions, attracts more hostility and generates more severe political opposition by host-country governments as was for example illustrated in 2006 by the failed attempt by Dubai World Ports to acquire P\&O. Cross-border majority purchases also bring regulators to require a higher level of transparency as evidenced recently by the EC Regulation dated 11 July 2017 that forces SWFs to provide more information for majority acquisitions in European companies. This question matters in the ongoing opportunity-threat debate, as it indicates what role SWFs want to take in their targets, and whether it differs across sectors, firms or countries.

The aim of this paper is to fill this gap in the literature by identifying the determinants of (minority and majority) cross-border acquisitions of SWFs originating from Gulf countries. 
Though SWFs are generally seen as heterogeneous investors with respect to their source and size of assets, organizational structure, governance, risk factor and their objectives, GCC SWFs present some key characteristics that make them a distinct group among SWFs. First, they are all funded by commodity revenues (mostly oil) meaning that their proceeds are extremely dependent on oil prices. Second, they are considered as relatively opaque investors and strongly politicized. Third, they come from autocratic countries. Finally, they are located in a same region, with common language and religion.

In particular, we study what determines the GCC SWFs' decisions to take control or large stakes in foreign firms. More specifically, we shed light on the real intention of SWFs when they decide to acquire a majority stake: Do GCC SWFs take cross-border majority stakes based on the financial health of the target firms? Based on the sectors, potentially strategic ones? Based on country specific characteristics (political or macroeconomic ones)?

Using an original large-scale database including both data on announced cross-border stakes done by GCC SWFs between 2006 and 2015, macroeconomic data on target countries as well as financial data on listed target firms, we use Logit models as well as ordered Logit models to explain the motivation of GCC SWFs to take cross-border large (> 10\%) or majority (>50\%) acquisitions.

Anticipating on our results, we find that financial characteristics of the target firms do not matter in the decision-making process of majority acquisition meaning that the decision of cross-border acquisition is not oriented towards risk-return and profit maximization objectives. Taking a majority stake is a specific decision going beyond investment purpose, where data tell that financial dimension play only a minor role, if any. In the same way, we find that transparent GCC SWFs are more likely to acquire large stakes and that they do so predominantly in: i) countries of the European Union; ii) countries with a high level of shareholders protection; iii) and in non-strategic sectors. These results altogether suggest that even if the motivations behind GCC SWFs majority acquisitions are other than pure profit maximisation, taking large stakes is not a mean for governments to acquire strategic 
interests abroad.

The paper is organized as follows. The next section introduces the hypotheses for analyzing GCC SWFs cross-border investment decisions. Section 3 provides details on our data. Section 4 presents the methodology and Section 5 reports our empirical findings.

\section{Review of literature and hypotheses}

There is an extensive literature investigating to what extent SWFs investment decisions differ from those of other institutional investors. Bernstein et al. (2013) explain that the presence of politicians inside the board of SWFs could lead to the search of strategic objectives and finally to financial and political destabilization. Dyck and Morse (2011) show that a part of SWFs portfolio is oriented toward the development of their domestic countries, indicating that investment decisions of SWFs are distorted by political considerations. Chhaochharia et al. (2009) find that SWFs show strong biases compared to other investors. More specifically, they find that SWFs are more likely to invest in countries that share a common culture and that they display industry biases, investing predominantly in oil company stocks. Knill et al. (2012) find that SWFs are more likely to invest in countries with which they have weaker political relations, implying that SWFs may invest, at least partly, for non-financial motives.

The findings that SWF investment decisions are dissimilar to those of traditional institutional investors can be explained by several factors. First, SWFs are sovereign-owned institution, which may be managed either by the ministry of finance or by a board composed of government officials. Unlike other funds, the politics or the structure of the fund owned/controlled directly by the government may influence asset allocation decisions. Second, in terms of social welfare, governments have broader goals than wealth maximisation of the firm, such as the development of the national economy or the maximisation of the employment level. Third, according to the natural resources curse theory (see among others Sachs and Warner (1995, 2001), Sala-i-Martin and Subramanian (2003) or Smith (2004)), countries with weak institutions generally have natural resource wealth that leads to resource 
dependency and rentierism. Even if the declared objective of these SWFs is to ensure that the proceeds from natural resources rents will be channelled through a transparent, accountable and professionally managed fund, they may be a mean for these autocratic countries to embezzle natural resources revenues in order to invest abroad (Carpantier and Vermeulen $(2018))$.

While there is an extensive literature that investigates the determinants of SWFs investment decisions, only few papers address the question of the determinants of cross-border majority purchases. Karolyi and Liao (2017) analyze cross-border majority acquisitions of government-led acquirers but do not focus on SWFs. Heaney et al. (2011) analyse the determinants of the level of SWFs investment, but their analysis focus on the Singaporean fund, Temasek Holdings. Murtinu and Scalera (2016) show that taking cross-border majority stakes is one driver of the use of investment vehicles by SWFs.

Large or majority acquisitions raise very specific questions for the following reasons. First, a large or a majority acquisition, potentially signals an activist stance and willingness to engage in effective corporate governance activities. Second, it can be part of a general commercial or industrial development strategy of the home country of the SWF. It allows the development of joint ventures and eases the strengthening of expertises or industrial complementarities relevant from the home country perspective (typically the downstream integration of energy value-chain). Third it signals that the investment might go beyond passive portfolio management and mean-variance optimization framework, which is quite obvious knowing that SWFs are government-owned entities.

Given these features, we now analyse the determinants of SWF majority acquisitions through 4 key hypotheses. 
H1 - GCC SWFs take cross-border majority stakes without considering the financial characteristics of the target.

As documented by Bernstein et al. (2013), the presence of politicians inside the board of the SWFs (which is the case for all GCC SWFs) leads to the search of strategic objectives not necessarily related to financial characteristics. An abundant literature (Chhaochharia et al. (2009), Ciarlone and Miceli (2016), Dyck and Morse (2011), Johan et al. (2013), Knill et al. (2012) among others) has shown that policy factors drive SWFs investment decisions.

At the same time, part of the literature shows that SWFs investment decisions are also financial (Fernandes (2014), Kotter and Lel (2011), Megginson et al. (2013)). Fernandes (2014) shows that SWFs tend to act as prudent investors, taking stakes in large firms with proven profitability. He also concludes that, given their long term investment horizon, SWFs have no preference for liquid stocks. Kotter and Lel (2011) find that SWFs tend to invest in large firms located in financially developed countries, exhibiting financial difficulties. They then deduce that SWFs are similar to institutional investors in their preference for target firm characteristics. Megginson et al. (2013) analyze the determinants of SWFs investment from the country perspective. They test if SWFs are purely commercial investors facilitating cross-border corporate investments or if their investment strategies are biased by political objectives. Their results suggest that SWFs make investment decisions principally for commercial purposes.

To the extent that control decisions potentially go beyond pure portfolio risk-return management, we expect the financial factors to have a low weight, if any, in the decision process. In other words, we test whether GCC SWFs take cross-border (full or partial) acquisitions based on financial variables, meaning that the decision of cross-border acquisition is, or not, oriented towards risk-return and profit maximisation objectives. 
H2 - GCC SWFs take the degree of financial and economic development of the target country into account before taking large or majority stakes.

Several papers study the impact of target country economic, financial and institutional development on the SWFs investment strategies. Some authors (Megginson et al. (2013) and Amar et al. (2018) among others) find that country factors do not explain SWFs investment decisions. On the contrary, Knill et al. (2012) find that SWFs are more likely to invest, and for larger amounts, in countries that have a level of economic development close to theirs. Ciarlone and Miceli (2016) find that SWFs tend to invest in countries that have a higher degree of economic development which is consistent with Karolyi and Liao (2017) who show that government-controlled investments flow from emerging to developed economies. Furthermore, the financial openness of the target country is one of the drivers of SWFs investments. Amar et al. (2018) and Ciarlone and Miceli (2016) show indeed that SWFs are more likely to invest in countries that are financially opened. Finally, some authors find that the level of investors protection significantly explain SWFs investment decisions. Knill et al. (2012) show that SWFs are more likely to invest in a country with a high level of investors protection, but when they do so, they tend to invest smaller amounts, which is consistent with Ciarlone and Miceli (2016) but not with Megginson et al. (2013) who find that a higher level of investors protection leads to larger amounts.

If the literature tells us that economic development, financial openness and the level of investors protection matter in SWFs investment decisions, the way these factors impact the decision is not unanimously accepted. These different results in the literature may be explained by the great heterogeneity of this group of investors. As we use here a homogenous group of SWFs (i.e. the GCC SWFs), we would like to test whether GCC SWFs take crossborder majority acquisitions by considering the economic and financial development of the target country.

H3 - GCC SWFs are more likely to take majority equity stakes in countries where there 
are bilateral trade agreements.

Majority acquisitions are expected to be part of a broader partnership between countries. We consider the impact of bilateral trade, financial or political agreements between SWF's and host countries on the acquisition decision. In line with Hoeckman and Kostecki (2009) and Murtinu and Scalera (2016), we refer to bilateral trade agreements as reflection of political relations and decisions among countries. As explained by Murtinu and Scalera (2016), international trade agreements first allow the government to signal a credible lasting commitment to liberal economic policies, limited intervention in the domestic economy and peaceful relations. Second, trade agreements are useful to reinforce political power. ${ }^{3}$ GCC countries have free trade agreements with some countries such as Singapore (GSFTA), or some European countries (The EFTA is a free trade agreement between GCC countries and Iceland, Lichtenstein, Norway and Switzerland). The existence of bilateral trade agreements between SWF's and target countries should facilitate the entrance of SWFs in foreign countries by reducing the risk perception related to SWFs investments and therefore by mitigating the potential fear against their acquisitions.

Some papers find that SWFs tend to invest in countries that are identified as trade partners (Megginson et al. (2013)). In the same way, Murtinu and Scalera (2016) find that bilateral trade agreements reduce the use of corporate investment vehicles for SWFs wishing to take cross-border majority acquisitions.

Related to this literature, we expect GCC SWFs to be more likely to take majority acquisitions overseas in countries bound by bilateral trade agreements.

\footnotetext{
${ }^{3}$ An example is the trade agreement between the US and 11 Asia-Pacific countries (the Trans-Pacific Partnership), where the exclusion of China by the US reveals the political nature of this agreement.
} 
H4 - GCC SWFs target cross-border companies operating in strategic industries.

The hostility of the host countries' public opinion and governments towards SWFs can be explained by the fact that SWFs might seek stakes in strategic sectors as defense, finance, telecommunication, energy or transportation (Dyck and Morse (2011)). This is the reason why many governments want to hinder foreign SWFs investments when the target is a strategic infrastructure or a sensitive firm operating in a strategic sector (Karolyi and Liao (2017), Knill et al. (2012)). Fernandes (2014) gives some examples of regulatory/enforcements efforts in order to hinder SWF investments: "The German government has announced that it would introduce controls on investments by SWFs, especially if they seek stakes in strategic sectors. French President Nicolas Sarkozy has announced that he would use his country's state-owned bank (Caisse des Dépôts et Consignations) to help protect French companies against potentiel takeover threats posed by SWFs".

As explained by Murtinu and Scalera (2016), the risk of political and financial destabilization for the host country is higher when the target investment is a strategic infrastructure. Two deal-level characteristics can explain the fear of the host country: i) the sector of the foreign target company; ii) the degree of control on this company. The larger the SWF's control on target firms operating in strategic industries, the more hostile host countries will be.

According to the literature on SWFs (Bernstein et al. (2013), Karolyi and Liao (2017), Murtinu and Scalera (2016)), three factors contribute to increase the probability of cross-border majority acquisitions in strategic industries: i) the undemocratic and authoritarian nature of the countries where SWFs originate from; ii) the high level of foreign currency reserves; iii) the involvement of politicians in the board of SWFs. As GCC combines these three factors, we expect that GCC SWFs target cross-border companies operating in strategic industries.

Furthermore, according to the portfolio allocation theory, SWFs may be used to diversify the industrial base of their home country by targeting foreign industries in which their country is under-represented. The political motives of cross-border SWFs acquisitions in 
strategic industries can therefore be explained by the search of a greater industrial diversification or a better access to lower-cost resource inputs. Regarding resource-rich countries like GCC, these countries are dependent on revenues from sales of energy, which makes these economies extremely vulnerable to changes in oil prices. It is fundamental for these countries to diversify their revenues by targeting foreign industries in which the country is under-represented (Sturm et al. (2008)). Therefore, the search of a greater industrial diversification may be a result of reducing dependency on oil revenues but also the search of strategic industrial gains in order to control access to technologies with the aim of maximizing long-term returns (Seznec (2008)). We then complement the sectoral focus by testing whether cross-border acquisitions are under-represented in energy sector.

\section{$3 \quad$ Data and descriptive analysis}

\subsection{The SWF sample}

According to the IMF (2004), "Sovereign wealth funds are government-owned investment funds set up for a variety a macroeconomic purposes". Considering this definition, we conducted a comprehensive search of all existing GCC SWFs and ultimately get 15 entities. We find 7 SWFs in the United Arab Emirates, 3 SWFs in Saudi Arabia, 2 SWFs in Oman, 1 in Bahrain, 1 in Kuwait and 1 in Qatar. Names, inception dates, estimated sizes are reported in Table 1. We then conducted a search of all wholly-owned subsidiaries of these funds using the online database Thomson Reuters Eikon and the funds' websites, which are also reported in Table 1, together with the Linaburg-Maduell transparency index (the higher the index, the more transparent the SWF) and the announced main objective(s) of the funds.

\subsection{Investment data}

We use Thomson Reuters Security Corporation's (SDC) Platinum Mergers and Acquisitions database to collect data on announced cross-border acquisitions done by GCC SWFs directly 


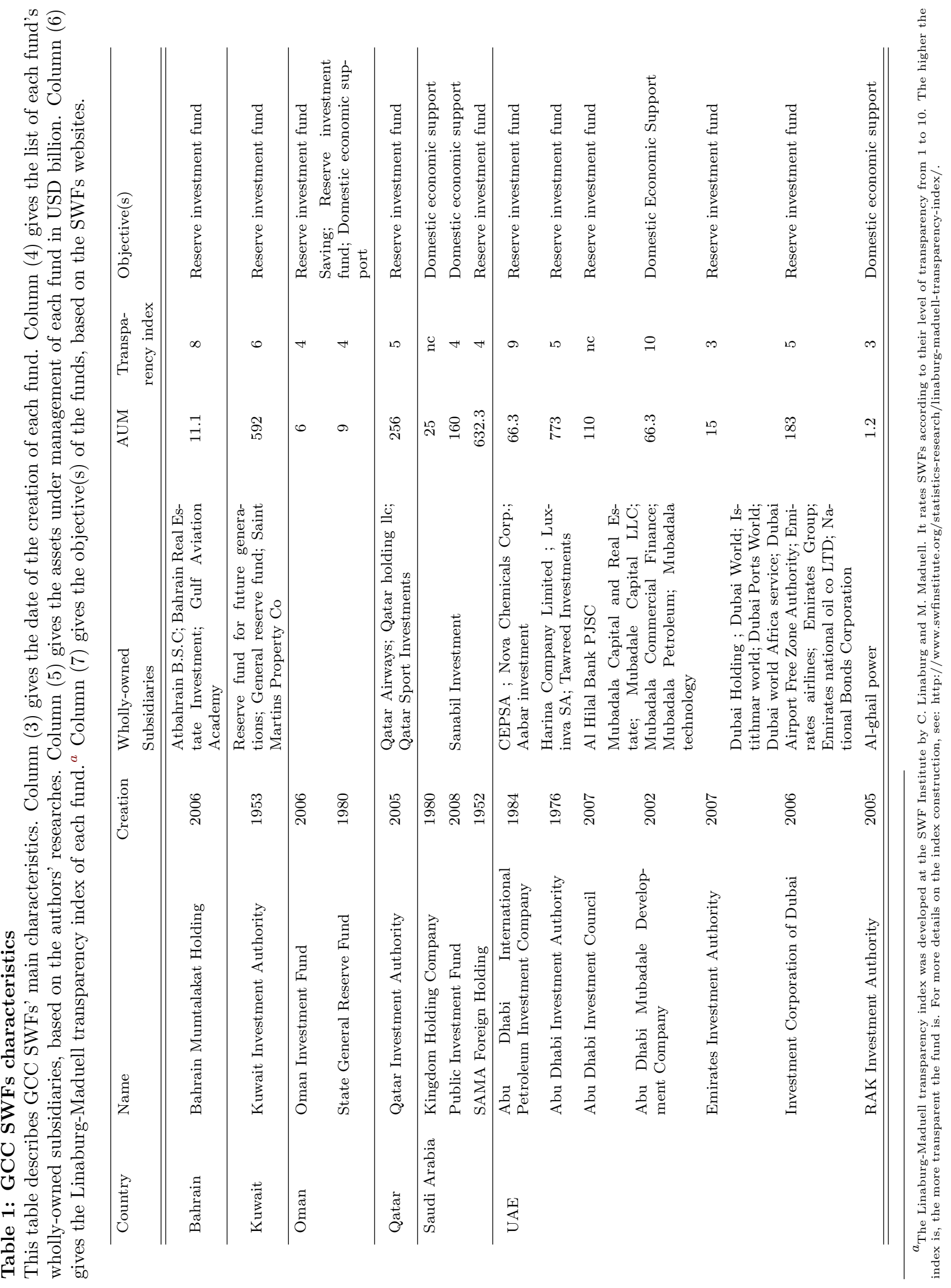


or by their wholly-owned subsidiaries. We doubled checked this list and completed the missing acquisitions by using the online database Factiva. We collected a number of data items, including information about the targeted firms (name, country), information about the SWFs (name, subsidiary, country), the date of the transaction, the pre- and post-acquisition share of the SWF in the targeted firm and the deal value, if disclosed. This search yields a sample of 124 cross-border acquisitions from GCC SWFs in 28 target countries over the period 2006-2015.

Our dependent variable is a discrete variable characterized by specific ownership share aimed at capturing the degree of acquisition in a target firm. We identify three levels of control, with thresholds at $10 \%$ and $50 \%$ of the target value. The first threshold follows the definition of Foreign Direct Investments (FDIs) according to which "a FDI (...) reflects the objective of a resident in one economy obtaining a lasting interest in an enterprise resident in another economy. (...) A direct investment relationship is established when the direct investor has acquired 10 percent or more of the ordinary shares or voting power of an enterprise abroad" (?). The second threshold is set at the majority stake. So, the first category of deals - called DEALS-10\% - include transactions where the SWFs take shares of the target such that their total holding is less than $10 \%$ (minor stakes). The second category - called $D E A L S+10 \%$ - collects the transactions leading to stakes larger than $10 \%$ but inferior to $50 \%$ (influential/large stakes). ${ }^{4}$ Following ?, we identify a third level of investment - called $D E A L S+50 \%$ - which includes transactions where the SWFs take shares such that the holdings are at least 50\% of the target (control/majority stakes).

Table 2 presents the number of cross-border deals by GCC SWFs over the period 20062015. We first note that 11 SWFs (out of the 15 SWFs identified for GCC countries) were found to effectively take cross-border acquisitions over 2006-2015, mainly those of Qatar and UAE, which together account for more than $90 \%$ of the deals. We also note that $40 \%$ of the deals are small deals $(<10 \%), 32 \%$ are minority deals (larger than $10 \%$ but inferior to $50 \%$ )

\footnotetext{
${ }^{4} 10 \%$ is also the relevant threshold used in the European legislation for defining "qualifying holdings" (Article 92 of Directive 2001/34/EC) and in the above-mentioned Commission Delegated Regulation (EU) $2017 / 1946$ of 11 July 2017.
} 
Table 2: Overview of SWFs' transactions

This table presents the number of deals and majority deals by GCC SWFs over the period 2006-2015. $D E A L S$ represents the total number of deals involving GCC SWFs. DEALS - $10 \%$ represents the number of deals in which the post-acquisition stakes owned by the SWFs is lower than $10 \%$. DEALS+10\% represents the number of deals in which the post-acquisition stakes owned by the SWFs is higher or equal to $10 \%$ and lower than 50\%. DEALS +50\% represents the number of deals in which the post-acquisition stakes owned by the SWFs is higher or equal to $50 \%$.

\begin{tabular}{|c|c|c|c|c|}
\hline SWF country & DEALS & DEALS- $10 \%$ & DEALS $+10 \%$ & DEALS $+50 \%$ \\
\hline $\begin{array}{l}\text { Abu Dhabi International Petroleum } \\
\text { Investment Company }\end{array}$ & 19 & 6 & 7 & 6 \\
\hline $\begin{array}{l}\text { Abu Dhabi Investment Authority } \\
\text { (UAE) }\end{array}$ & 11 & 8 & 1 & 2 \\
\hline $\begin{array}{l}\text { Abu Dhabi Mubadala Development } \\
\text { Company (UAE) }\end{array}$ & 11 & 2 & 5 & 4 \\
\hline $\begin{array}{l}\text { Investment corporation of Dubai } \\
\text { (UAE) }\end{array}$ & 20 & 6 & 6 & 8 \\
\hline Kuwait Investment Authority & 6 & 3 & 2 & 1 \\
\hline Oman Investment Fund & 2 & 1 & 0 & 1 \\
\hline Public Investment Fund (SA) & 1 & 0 & 1 & 0 \\
\hline Qatar Investment Authority & 50 & 21 & 18 & 11 \\
\hline RAK Investment authority (UAE) & 1 & 1 & 0 & 0 \\
\hline SAMA Foreign Holding (SA) & 1 & 1 & 0 & 0 \\
\hline State General Reserve Fund (Oman) & 2 & 1 & 0 & 1 \\
\hline \multirow[t]{2}{*}{ Total } & 124 & 50 & 40 & 34 \\
\hline & $100 \%$ & $40 \%$ & $32 \%$ & $27 \%$ \\
\hline
\end{tabular}

and finally $27 \%$ of the deals are majority transactions (larger than $50 \%$ ).

Figure 1 shows the evolution of GCC SWFs foreign investments over the period 20062015. This figure reveals that GCC SWFs have a tendency to acquire large stakes as the average post-acquisition share is larger than $19 \%$ every year. During the financial crisis (2008-2009), SWFs made more investments but have reduced the size of their stakes. This is linked with the large number of investments made in financial institutions, such as Qatar Investment Authority investing in Barclays Bank or Abu Dhabi Investment Authority investing in Citigroup. After the crisis, the number of acquisitions decreased in number but not in value. After 2013, the average post-acquisition share was higher than $30 \%$.

Table 3 gives the geographic distribution of GCC SWFs cross-border acquisitions. More than half of the transactions done by GCC are located in Europe and they are mainly majority acquisitions (64\% of the deals are post-transaction shares of $10 \%$ or more and $32 \%$ are shares of $50 \%$ or more). The other target regions are North America (almost $13 \%$ of total deals) with mainly minority investments (63\% of deals less than $10 \%$ of shares) and East and Southeast Asia (10\% of total deals) with larger stakes (62\% of deals of more than 
Figure 1: Evolution of GCC SWFs Foreign Investments

This Figure presents the number of deals and the average post-acquisition stake of cross-border investments led by GCC SWFs over the period 2006-2015. The graph excludes investments of Qatar Investment Authority in Xstrata which consists in 39 acquisitions of less than 1\% of the target firm.

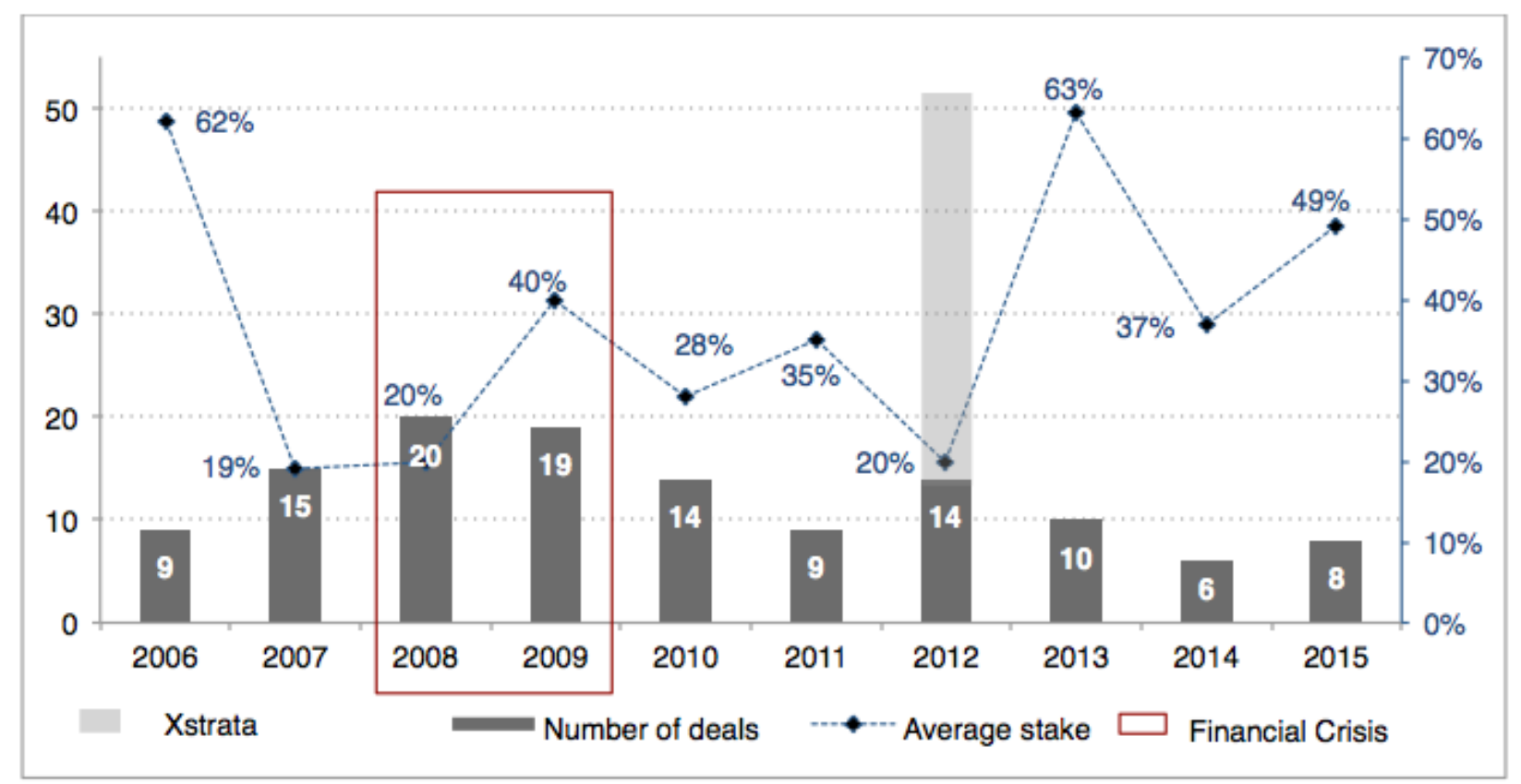

$10 \%$ of shares). On the other hand, the other regions like Africa and South America do not attract GCC SWFs, as they have invested only four times in these regions over the period 2006-2015.

Table 4 gives the sectorial repartition of GCC SWFs acquisitions and majority acquisitions over 2006-2015. Energy, finance, industry and luxury are key sectors and account each for more than $10 \%$ of the deals (even $20 \%$ for the energy sector). We also note that $50 \%$ of the deals in the luxury sector are majority deals, while they represent only $14 \%$ and $16 \%$ respectively for finance and industry sectors.

\subsection{Explanatory variables}

We employ a number of variables that should potentially explain the decision to acquire minority/majority stakes for GCC SWFS. These variables relate to macroeconomic and institutional target country factors, firm-level characteristics as well as the type of investment 
Table 3: Geographic repartition of GCC SWF cross-border investments

This table presents the number of deals and majority deals by target region of cross-border investments led by GCC SWFs over the period 2006-2015. DEALS represents the total number of deals involving GCC SWFs. DEALS - 10\% represents the number of deals in which the post-acquisition stakes owned by the SWFs is lower than $10 \%$. DEALS $+10 \%$ represents the number of deals in which the post-acquisition stakes owned by the SWFs is higher or equal to $10 \%$ and lower than $50 \%$. DEALS $+50 \%$ represents the number of deals in which the post-acquisition stakes owned by the SWFs is higher or equal to $50 \%$.

\begin{tabular}{|c|c|c|c|c|}
\hline Region target & DEALS & DEALS- $10 \%$ & DEALS+10\% & DEALS+50\% \\
\hline \multirow[t]{2}{*}{ Africa } & 3 & 3 & 0 & 0 \\
\hline & $100 \%$ & $100 \%$ & $0 \%$ & $0 \%$ \\
\hline \multirow[t]{2}{*}{ Central Asia } & 6 & 3 & 1 & 2 \\
\hline & $100 \%$ & $50 \%$ & $17 \%$ & $33 \%$ \\
\hline \multirow[t]{2}{*}{ East and Southeast Asia } & 13 & 3 & 8 & 2 \\
\hline & $100 \%$ & $23 \%$ & $62 \%$ & $15 \%$ \\
\hline \multirow[t]{2}{*}{ North America } & 16 & 10 & 3 & 3 \\
\hline & $100 \%$ & $63 \%$ & $19 \%$ & $19 \%$ \\
\hline \multirow[t]{2}{*}{ Oceanic Bassin } & 8 & 4 & 2 & 2 \\
\hline & $100 \%$ & $50 \%$ & $25 \%$ & $25 \%$ \\
\hline \multirow[t]{2}{*}{ South America } & 1 & 0 & 1 & 0 \\
\hline & $100 \%$ & $0 \%$ & $100 \%$ & $0 \%$ \\
\hline \multirow[t]{2}{*}{ Europe } & 77 & 27 & 25 & 25 \\
\hline & $100 \%$ & $35 \%$ & $32 \%$ & $32 \%$ \\
\hline \multirow[t]{2}{*}{ Total } & 124 & 50 & 40 & 34 \\
\hline & $100 \%$ & $40 \%$ & $32 \%$ & $27 \%$ \\
\hline
\end{tabular}

Table 4: Sectoral repartition of GCC SWF cross-border investments

This table presents the number of cross-border deals and majority deals by target sectors led by GCC SWFs over the period 2006-2015. DEALS represents the total number of deals involving GCC SWFs. $D E A L S-10 \%$ represents the number of deals in which the post-acquisition stakes owned by the SWFs is lower than 10\%. DEALS $+10 \%$ represents the number of deals in which the post-acquisition stakes owned by the SWFs is higher or equal to $10 \%$ and lower than $50 \%$. DEALS+50\% represents the number of deals in which the post-acquisition stakes owned by the SWFs is higher or equal to $50 \%$.

\begin{tabular}{lllll}
\hline Sector target & DEALS & DEALS-10\% & DEALS+10\% & DEALS+50\% \\
\hline \hline Energy & 30 & 14 & 9 & 7 \\
& $100 \%$ & $47 \%$ & $30 \%$ & $23 \%$ \\
\hline Finance & 14 & 8 & 4 & 2 \\
& $100 \%$ & $57 \%$ & $29 \%$ & 3 \\
\hline Industry & 19 & 9 & $37 \%$ & $16 \%$ \\
& $100 \%$ & $47 \%$ & 4 & 9 \\
\hline Luxury & 18 & 5 & $22 \%$ & $30 \%$ \\
\hline Real Estate & $100 \%$ & $28 \%$ & 3 & $33 \%$ \\
& 9 & 3 & 1 & 1 \\
\hline Transportation & $100 \%$ & $33 \%$ & $14 \%$ & $14 \%$ \\
& 7 & 5 & 12 & 9 \\
\hline Other & $100 \%$ & $71 \%$ & $44 \%$ & $33 \%$ \\
\hline Total & 27 & 6 & 40 & 34 \\
& $100 \%$ & $22 \%$ & $32 \%$ & $27 \%$ \\
\hline \hline
\end{tabular}

sectors. Details on variables construction and source are presented in Table 5.

Target firm/sector specific variables: 
Table 5: Description of the variables

\begin{tabular}{|c|c|c|}
\hline Variables & Description & Source \\
\hline \multicolumn{3}{|c|}{ Target firm specific variables } \\
\hline ASSETS & Mean of the total assets in $t-1, t-2, t-3$ of the targeted firm & Orbis database \\
\hline ROA & Mean of the ROA in $t-1, t-2, t-3$ of the targeted firm & Orbis database \\
\hline DEBT/ASSETS & $\begin{array}{l}\text { Ratio between the mean of the long term debt in } t-1, t-2, t-3 \\
\text { and the total assets in } t-1, t-2, t-3 \text { of the targeted firm }\end{array}$ & Orbis database \\
\hline LIQUIDITY & Mean of the liquidity ratio in $t-1, t-2$ and $t-3$ of the targeted firm & Orbis database \\
\hline DEBT & Mean of the long term in $t-1, t-2$ and $t-3$ of the targeted firm & Orbis database \\
\hline SECTORS & $\begin{array}{l}\text { Targeted firms sectors include energy, finance, industry, luxury, real } \\
\text { estate, transportation and others. }\end{array}$ & Authors' analysis \\
\hline \multicolumn{3}{|c|}{ Target country specific variables } \\
\hline GDP & GDP per capita of the target country of year $t-1$ & The World Bank \\
\hline EU DUMMY & $\begin{array}{l}\text { Dummy variable equals to } 1 \text { if the target country is in the Europe, } \\
\text { and } 0 \text { otherwise }\end{array}$ & Authors' analysis \\
\hline ANTISELF & $\begin{array}{l}\text { Anti-self dealing index of the target country. The anti-self dealing } \\
\text { index is a measure of legal protection of minority shareholders against } \\
\text { expropriation by corporate insiders }\end{array}$ & Djankov et al. (2005) \\
\hline dlogREER & $\begin{array}{l}\text { Consumer price index-based real effective exchange rate of the tar- } \\
\text { geted country. Mean of dlog over } t-1, t-2 \text { and } t-3 \text {. Positive } \\
\text { variation is an appreciation }\end{array}$ & Bruegel Database \\
\hline $\operatorname{logKAOPEN}$ & $\begin{array}{l}\text { Logarithm of the normalized KAOPEN index of the targeted country } \\
\text { in } t-1 \text {. Initially introduced by Chinn and Ito }(2006) \text {, this index } \\
\text { measures a country's degree of capital account openness }\end{array}$ & Chinn-Ito website \\
\hline POLITY & $\begin{array}{l}\text { Polity IV score of the targeted country the year before the transac- } \\
\text { tion. The score captures the regime authority spectrum on a } 21 \text {-point } \\
\text { scale ranging from }-10 \text { (hereditary monarchy) to }+10 \text { (consolidated } \\
\text { democracy) }\end{array}$ & Polity IV Project \\
\hline \multicolumn{3}{|c|}{ SWF specific variables } \\
\hline SIZESWF & Size of SWF assets under management (USD billion). & SWF Institute \\
\hline TRANSPARENT & $\begin{array}{l}\text { Dummy variable equals to } 1 \text { if the Lindaburg-Maduell Transparency } \\
\text { index of the SWF is higher than } 5 \text { and } 0 \text { otherwise. The index ranges } \\
\text { between } 0 \text { and } 10 \text {. The higher the index is, the more transparent is } \\
\text { the SWF }\end{array}$ & SWF Institute \\
\hline SUBSIDIARY & $\begin{array}{l}\text { Dummy variable equals to } 1 \text { if the acquisition was made by a sub- } \\
\text { sidiary of the SWF and } 0 \text { otherwise }\end{array}$ & Factiva (mainly) \\
\hline \multicolumn{3}{|l|}{ Additional controls } \\
\hline CRISIS & Dummy variable equals to 1 in 2008 and 2009, and 0 otherwise & Authors' analysis \\
\hline FTAFORCE & $\begin{array}{l}\text { Dummy variable equals to } 1 \text { if there is a free-trade agreement in force } \\
\text { between the country of the SWF and the target country, and } 0 \text { oth- } \\
\text { erwise }\end{array}$ & Governments' websites \\
\hline FTANEGO & $\begin{array}{l}\text { Dummy variable equals to } 1 \text { if there is a free-trade agreement in force } \\
\text { or under negotiations between the country of the SWF and the target } \\
\text { country, and } 0 \text { otherwise }\end{array}$ & Governments' websites \\
\hline $\log$ OILPRICE & Logarithm of the average crude WTI crude oil price in year $t-1$ & FRED database \\
\hline
\end{tabular}

In order to test whether target firm-level variables are determinants of minority/majority acquisitions for GCC SWFs (H1), the variables collected for each of the targeted firms included in the sample can be allocated to the broad classifications, performance, risk 
and liquidity. Returns on assets $(R O A)$ is used in order to capture target firm performance, $L I Q U I D I T Y$ is the liquidity ratio of the target firm, DEBT is the long term debt level of the firm and $D E B T / A S S E T S$ is the ratio of long term debt on assets. These four financial variables are based on the three years preceding the investment in order to take into account the information available at the time of the investment.

In addition to variables related to the financial performance of the firm, we also use the target firms' sectors as explanatory variables (LUXURY, FINANCE, ENERGY, INDUSTRY, METAL)and test whether GCC SWFs have an incentive to target crossborder companies operating in strategic industries as explained in $\mathrm{H} 4$.

\section{Target country specific variables:}

In order to test whether the economic development of the target country matters in the GCC SWF-led acquisition activity (see H2), we include several country-level variables that have been shown in the literature to be related to international investment choices of SWFs (Fernandes (2014)). Like (Karolyi and Liao (2017), we use the anti-self-dealing index (ANTISELF) constructed by Djankov et al. (2008) measuring the ex-ante and ex-post effectiveness of regulation and enforcement against violators. The Chinn-Ito financial openness index of the target country (logKAOPEN) initially introduced by Chinn and Ito (2006) measures the target country's degree of capital account openness. POLITY captures the level of authority of the targeted country as defined by the Polity IV database. Like in Hay and Milelli (2014), a regional dummy (EU DUMMY) for Europe is also included. This dummy variable equals 1 if the target country is in Europe and 0 otherwise. As macroeconomic performance indicators, the Gross Domestic Product per capita $(G D P)$ of the target country is included in order to capture the relative size of the target country economy. At last, we consider the real effective exchange rate variations of the target country in logarithmic form $(d \log R E E R)$ as indicator of gain/loss of competitiveness. 
SWF specific variables

Finally, we include variables measuring characteristics of each GCC SWF, including its size $(S I Z E)$ measured as the value of the assets under management, a transparency index (TRANSPARENT) which is a dummy variable equals 1 if the Linaburg-Maduell Transparency index of the fund is higher than 5 and 0 otherwise and a dummy called SUBSIDIARY indicating if GCC SWFs are more prone to take majority acquisition through a wholly-owned subsidiary as in Murtinu and Scalera (2016) .

\section{Additional controls}

We finally include the WTI oil price level (OILPRICES) because commodity trade resources may be the main driver of GCC SWFs strategies and a dummy variable that identifies the financial crisis (CRISIS), equals 1 if the transaction occurs in 2008 or 2009, and zero otherwise. In order to test whether GCC SWFs are more likely to take majority stakes in countries where there are bilateral trade agreements (H3), two proxies of bilateral trade agreement are considered: FTAFORCE which is a dummy variable equals 1 if there is a free trade agreement in force between the SWF's country and the targeted firm's country, and 0 otherwise and FTANEGO which is a dummy variable equals 1 if there is a free trade agreement under negotiation between the SWF's country and the targeted firm's country, and 0 otherwise.

\section{Empirical Part}

We first provide some preliminary insights into the data by estimating two separate Logit models based on the $10 \%$, and $50 \%$ thresholds respectively. We then estimate a multinomial ordered Logit model designed to better fit the investment decision-making process of SWFs. We finally discuss our results and compare them to the main outcomes of the literature on SWFs' investment decisions. 


\subsection{Preliminary findings with binary Logit models}

We model the probability of taking a majority (resp. large) stake in the target firm as a function of the explanatory variables described above (target firm variables, target country variables, SWF specific variables as well as additional control variables), by relying on the Logit specification. The model is defined as follows:

$$
\operatorname{Prob}\left(Y_{i j}=1 \mid X\right)=\Lambda(X \beta)=\frac{e^{X \beta}}{1+e^{X \beta}}
$$

where $Y_{i j}$ is a dummy variable equal to 1 if the fund $i$ takes a stake of $10 \%$ or more (resp. $50 \%$ or more) in a cross-border firm $j$ and to 0 otherwise, where $\beta$ is the coefficient vector, $X$ is the vector of explanatory variables and $\Lambda($.$) is the standard logistic distribution function. { }^{5}$ Relying on a distribution function, like the logistic, ensures that we get values between zero and one, as we expect from a probability. ${ }^{6}$ We thus test our hypotheses respectively on the determinants of GCC SWFs large $(+10 \%)$ and majority $(+50 \%)$ cross-border acquisitions and report the estimation results in Table 6 for full models (columns (1) and (3)) and then, by applying a general-to-specific backward-selection approach, for parsimonious models (columns (2) and (4)).

First, the results of the Logit estimations, based on the parsimonious models, show that the large or majority acquisition decisions are not necessarily determined by the same set of explanatory variables. We thus note that the variables dlogREER, POLITY, LUXURY, SIZESWF, FTANEGO, ROA and CRISIS are significant in the model with threshold at $50 \%$ but not in the model with threshold at $10 \%$. We find the reverse for the variables TRANSPARENT, EU DUMMY, OILPRICES, FINANCE and ENERGY. This difference of results in the two binary Logit models confirms the relevance of considering different thresholds in our analysis.

\footnotetext{
${ }^{5}$ Similar results are obtained by relying on probit rather than Logit models. Results are available on request.

${ }^{6}$ The Logit model can also be derived from underlying behavioural assumptions, which lead to a latent variable representation of the model (see Wooldridge (2010) and the next sub-section where this approach is presented in a more general 3-discrete choice framework).
} 
Table 6: Logit models - influential stakes and majority stakes

This table reports the results of separate estimations of Logit models with robust errors. In models (1) and (2) (resp. (3) and (4)), the endogenous variable $\left(Y_{i j}\right)$ is a dummy variable equals to zero if the posttransaction share of the SWF $i$ in the target $j$ is smaller than $10 \%$ (resp. 50\%), and equals to one if its is larger or equal. Columns (1) and (3) report the estimates for the full models, while columns (2) and (4) report the parsimonious model resulting from a backward-selection approach with significance level for removal of the model set at $10 \%$.

\begin{tabular}{|c|c|c|c|c|}
\hline \multirow{3}{*}{ TRANSPARENT } & \multirow{2}{*}{\multicolumn{2}{|c|}{$\begin{array}{l}\text { INFLUENTIAL STAKE }(+10 \%) \\
(1)\end{array}$}} & \multicolumn{2}{|c|}{ MAJORITY STAKE (+50\%) } \\
\hline & & & (3) & (4) \\
\hline & $\begin{array}{l}1.461^{*} \\
(0.789)\end{array}$ & $\begin{array}{c}1.274^{* *} \\
(0.608)\end{array}$ & $\begin{array}{c}1.228 \\
(0.768)\end{array}$ & \\
\hline SUBSIDIARY & $\begin{array}{c}0.332 \\
(0.543)\end{array}$ & & $\begin{array}{l}-0.106 \\
(0.667)\end{array}$ & \\
\hline EUDUMMY & $\begin{array}{c}1.080 \\
(0.696)\end{array}$ & $\begin{array}{c}1.215^{* * *} \\
(0.455)\end{array}$ & $\begin{array}{c}0.167 \\
(1.207)\end{array}$ & \\
\hline ANTISELF & $\begin{array}{c}1.987^{*} \\
(1.099)\end{array}$ & $\begin{array}{c}2.041^{* *} \\
(0.865)\end{array}$ & $\begin{array}{c}3.795 * * \\
(1.603)\end{array}$ & $\begin{array}{c}3.150^{* * *} \\
(1.112)\end{array}$ \\
\hline OILPRICE & $\begin{array}{c}1.966 \\
(1.222)\end{array}$ & $\begin{array}{l}1.937^{*} \\
(1.057)\end{array}$ & $\begin{array}{c}0.851 \\
(1.591)\end{array}$ & \\
\hline ROA & $\begin{array}{c}-0.010 \\
(0.021)\end{array}$ & & $\begin{array}{c}-0.040 \\
(0.025)\end{array}$ & $\begin{array}{c}-0.036^{* *} \\
(0.017)\end{array}$ \\
\hline DEBTASSETS & $\begin{array}{l}-0.638 \\
(0.889)\end{array}$ & & $\begin{array}{l}-1.359 \\
(1.035)\end{array}$ & \\
\hline LIQUIDITY & $\begin{array}{c}0.015 \\
(0.070)\end{array}$ & & $\begin{array}{c}0.071 \\
(0.069)\end{array}$ & \\
\hline DEBT & $\begin{array}{c}0.002 \\
(0.007)\end{array}$ & & $\begin{array}{l}-0.004 \\
(0.009)\end{array}$ & \\
\hline ASSETS & $\begin{array}{l}-0.000 \\
(0.003)\end{array}$ & & $\begin{array}{c}0.004 \\
(0.005)\end{array}$ & \\
\hline CRISIS & $\begin{array}{c}0.160 \\
(0.598)\end{array}$ & & $\begin{array}{c}-2.359^{* * *} \\
(0.790)\end{array}$ & $\begin{array}{c}-2.118^{* * *} \\
(0.665)\end{array}$ \\
\hline FTAFORCE & $\begin{array}{c}1.339 \\
(1.118)\end{array}$ & & $\begin{array}{c}-1.329 \\
(1.166)\end{array}$ & \\
\hline FTANEGO & $\begin{array}{c}0.056 \\
(0.606)\end{array}$ & & $\begin{array}{l}-1.595 \\
(1.295)\end{array}$ & $\begin{array}{c}-1.466^{* *} \\
(0.661)\end{array}$ \\
\hline dlogREER & $\begin{array}{c}4.061 \\
(2.755)\end{array}$ & & $\begin{array}{c}10.609^{* *} \\
(4.448)\end{array}$ & $\begin{array}{c}9.113^{* *} \\
(3.628)\end{array}$ \\
\hline GDP & $\begin{array}{l}-0.025 \\
(0.018)\end{array}$ & & $\begin{array}{c}0.011 \\
(0.026)\end{array}$ & \\
\hline $\operatorname{logKAOPEN}$ & $\begin{array}{c}0.946 \\
(0.781)\end{array}$ & & $\begin{array}{c}0.039 \\
(1.173)\end{array}$ & \\
\hline LUXURY & $\begin{array}{c}0.433 \\
(0.656)\end{array}$ & & $\begin{array}{c}2.272^{* * *} * \\
(0.849)\end{array}$ & $\begin{array}{c}2.191^{* * *} * \\
(0.635)\end{array}$ \\
\hline FINANCE & $\begin{array}{c}-1.491^{*} \\
(0.889)\end{array}$ & $\begin{array}{c}-1.702^{* *} \\
(0.766)\end{array}$ & $\begin{array}{c}-1.259 \\
(1.131)\end{array}$ & \\
\hline ENERGY & $\begin{array}{c}-1.450^{*} \\
(0.796)\end{array}$ & $\begin{array}{c}-1.376^{* *} \\
(0.589)\end{array}$ & $\begin{array}{c}-0.737 \\
(0.873)\end{array}$ & \\
\hline INDUSTRY & $\begin{array}{c}-0.895 \\
(0.803)\end{array}$ & & $\begin{array}{c}-1.688 \\
(1.762)\end{array}$ & \\
\hline SIZESWF & $\begin{array}{l}-0.001 \\
(0.001)\end{array}$ & & $\begin{array}{c}-0.003 \\
(0.003)\end{array}$ & $\begin{array}{c}-0.003^{*} \\
(0.002)\end{array}$ \\
\hline POLITY & $\begin{array}{c}0.006 \\
(0.062)\end{array}$ & & $\begin{array}{c}0.116 \\
(0.096)\end{array}$ & $\begin{array}{c}0.141^{*} \\
(0.076)\end{array}$ \\
\hline _cons & $\begin{array}{l}-8.780 \\
(5.671) \\
\end{array}$ & $\begin{array}{c}-9.847^{* *} \\
(4.734) \\
\end{array}$ & $\begin{array}{c}-6.877 \\
(7.567) \\
\end{array}$ & $\begin{array}{c}-2.800^{* *} \\
(1.165) \\
\end{array}$ \\
\hline Log-likelihood & -68.449 & -73.626 & -51.611 & -57.257 \\
\hline AIC & 182.898 & 161.252 & 149.223 & 132.514 \\
\hline $\mathrm{BIC}$ & 247.764 & 180.994 & 214.089 & 157.897 \\
\hline
\end{tabular}


Concerning firm-level factors, the results support H1 as we find no evidence that GCC SWFs would consider the financial characteristics of the target firm. Except for the variable $R O A$, all the variables on the financial characteristics of the target firm are not significant. Consistently with Kotter and Lel (2011) and Bernstein et al. (2013) who find that SWFs invest in distressed firms, we find that GCC SWFs prefer to take cross-border majority acquisitions in firms with low profitability $(R O A)$, suggesting that GCC SWFs are passive shareholders with a long-run investment horizon.

Regarding H2 which stresses that GCC SWFs take cross-border acquisitions by considering the economic and financial development of the target country, the significance of REER, POLITY, ANTISELF and EU DUMMY clearly reveals that country factors are essential in the GCC SWFs acquisition decision making-process. REER is positively related to majority acquisitions, meaning that these funds are more likely to take majority stakes in countries where the real effective exchange rate is high, i.e. where there is a loss of price competitiveness. In the same way, we find that GCC SWFs are more prone to take large stakes or the control of a firm in countries where there is a high quality of investors protection, unlike ? who find that cross-border majority acquisitions of government-led acquirers are weakly related to anti-self dealing index differences. In addition, the variable $E U D U M M Y$ is found significant in the sense that GCC SWFs target countries of the European Union when they take influential (10\% or more) stakes. This result is consistent with Hay and Milelli (2014) who find that Europe is the privileged destination for Middle Eastern SWFs. ${ }^{7}$

Unlike Megginson et al. (2013) and Knill et al. (2012), we do not find a significantly positive role for bilateral trade or political agreement in facilitating influential or majority acquisitions in target countries. H3 is by consequence not supported by the data as the variable FTAFORCE is never significant and FTANEGO is found negatively significant for decisions to take majority stakes and not significant in the large stake decision setup.

\footnotetext{
${ }^{7}$ GCC SWFs have several partnerships with European companies. For example, the SWF of Abu Dhabi has partnerships with Airbus and Total from France, Siemens from Germany or Rolls-Royce from UK.
} 
In order to analyse the political motivation of GCC SWFs, we have tested whether these funds seek majority stakes in strategic sectors as explained in the H4. We find that the dummy $L U X U R Y$ is significantly positive in the second model, meaning that GCC SWFs are more prone to take majority stakes in the luxury sector. On the other hand, the variables FINANCE and ENERGY are negatively related to influential acquisitions made by GCC SWFs. Concerning the financial sector, our result can be explained, first by regulatory/enforcements efforts made by developed countries (especially US and the European countries) in order to hinder SWFs majority acquisitions in this sector, and second by the large size of firms operating in this sector (a large amount may correspond to a minority stake). In the same way, we find that cross-border influential acquisition (more than $10 \%$ ) of Gulf SWFs are under-represented in the energy sector, indicating that resource-rich countries, that are extremely dependent on revenues from oil and gas, try to diversify their revenues by targeting foreign industries in which the country is under-represented.

Concerning the SWF-level variables, we find that the probability for GCC SWFs of taking an influential (10\% or more) stake in a cross-border industry is positively related with the transparency of the fund. Similarly, the probability of taking majority ( $50 \%$ or more) stake is negatively related to the size of the SWF. A small and/or transparent SWF are therefore less likely to raise hostility and political pressure from the host country's government increasing therefore the probability of influential/control stakes. The result is in line with Murtinu and Scalera (2016) who find that opaque SWFs are more likely to invest cross-border through an investment vehicle than transparent SWFs in order to show a passive investment approach and reduce the political pressure in the host country.

Turning to our control variables, we unsurprisingly see that oil trade resources are a driver of GCC SWFs large acquisitions. Hay and Milelli (2014) also find that the number of acquisitions has followed the same orientation than crude oil prices. Interestingly, our results show that GCC SWFs have limited their cross-border majority acquisitions (50\% or more) during the financial crisis. 


\subsection{Ordered Logit Analysis}

\subsubsection{The model}

Although informative, the separate (binary) Logit estimates are not fully satisfactory. First, the results for our two specifications (thresholds at $10 \%$ and $50 \%$ ) are not always in line and their consistency cannot be easily tested in such setting. Second, the SWF investment decision is a 1-step decision in a 3-choice setting and not a set of two independent binary decisions as implied by the Logit approach. We thus need a multinomial discrete (three) choice model able to capture an efficient/simultaneous estimate of the parameters since SWFs have to decide either to stay minority shareholders (stake of less than 10\%) in the foreign industry or to take more than $10 \%$ but less than $50 \%$ in order to have a significant influence on the management of the target or to take the control of the firm (more than $50 \%)$.

The ordered Logit model meets these requirements and addresses well for the specificities of the SWFs investment decision making-process. ${ }^{8}$ Number of studies such as Ederington (1985) or Poon (2007) illustrate the relevance of considering ordered Logit models in explaining and predicting similar ordered categorical variables such as bond or credit rating (see also Wooldridge (2010) and Long and Freese (2014)).

In our set-up, we define $Y_{i j}$, the degree of acquisition of the fund $i$ in a target $j$ as follows: ${ }^{9}$

$$
\begin{cases}Y=0 & \text { if the post-transaction share is less than } 10 \% \\ Y=1 & \text { if the post-transaction share is between } 10 \% \text { and } 50 \% \\ Y=2 & \text { if the post-transaction share is more than } 50 \%\end{cases}
$$

Similarly to the (binary) Logit model, the ordered Logit model can be derived from an

\footnotetext{
${ }^{8}$ Ordered Logit models rely on the parallel regression assumption. A more general model, so-called generalized ordered Logit model (Long and Freese (2014)) relaxes this assumption. We performed a Wald test developed by Brant (1990) in order to discriminate between the ordered Logit model and the generalized ordered Logit model. Results confirm that the ordered Logit model is not rejected and best fit our data. Results are available upon request.

${ }^{9}$ We will no longer explicitly refer to $i j$ subscripts in view to simplify notations
} 
underlying latent variable $Y^{*}$ determined as follows:

$$
\left\{\begin{array}{l}
Y^{*}=X \beta+e, \quad e \mid X \sim \Lambda\left(0, \frac{\pi^{2}}{3}\right) \\
Y=k \quad \text { if } \quad \alpha_{k}<Y^{*} \leq \alpha_{k+1} \quad k=0,1.2
\end{array}\right.
$$

where $\beta$ is the coefficient vector, $X$ is the vector of explanatory variables, $\Lambda($.$) is the standard$ logistic distribution function, $\alpha_{0}=-\infty, \alpha_{3}=+\infty$, and $\alpha_{1}$ and $\alpha_{2}$ are unknown parameters. As $Y^{*}$ crosses unknown thresholds $\alpha_{1}$ or $\alpha_{2}$, we move up the ordering of alternatives. For example, with a very low $Y^{*}$, i.e. smaller than $\alpha_{1}$, we get a minority stake. For a very high $Y^{*}$, i.e. larger than $\alpha_{2}$, we get a majority stake.

We can then easily compute the conditional choice probabilities:

$$
\left\{\begin{array}{l}
P(Y=0 \mid X)=P\left(Y^{*} \leq \alpha_{1} \mid X\right)=\frac{1}{1+\exp \left(X \beta-\alpha_{1}\right)} \\
P(Y=1 \mid X)=P\left(\alpha_{1}<Y^{*} \leq \alpha_{2} \mid X\right)=\frac{1}{1+\exp \left(X \beta-\alpha_{2}\right)}-\frac{1}{1+\exp \left(X \beta-\alpha_{1}\right)} \\
P(Y=2 \mid X)=P\left(Y^{*}>\alpha_{2} \mid X\right)=1-\frac{1}{1+\exp \left(X \beta-\alpha_{2}\right)}
\end{array}\right.
$$

The cut-points $\alpha_{1}, \alpha_{2}$ and the parameters $\beta$ are estimated by maximum likelihood. The interpretation of the $\beta$ s are of limited interest as they relate to $Y^{*}$ while our focus is on the categorical variable $Y$. We will thus report in the results section the partial effects of $X_{k}$ on the probabilities, which are computed as follows for the continuous explanatory variables:

$$
\left\{\begin{array}{l}
\partial P(Y=0 \mid X) / \partial X_{k}=-\left(\frac{\exp \left(X \beta-\alpha_{1}\right)}{\left(1+\exp \left(X \beta-\alpha_{1}\right)\right)^{2}}\right) \beta_{k} \\
\partial P(Y=1 \mid X) / \partial X_{k}=\left(\frac{\exp \left(X \beta-\alpha_{2}\right)}{\left(1+\exp \left(X \beta-\alpha_{2}\right)\right)^{2}}-\frac{\exp \left(X \beta-\alpha_{1}\right)}{\left(1+\exp \left(X \beta-\alpha_{1}\right)\right)^{2}}\right) \beta_{k} \\
\partial P(Y=2 \mid X) / \partial X_{k}=\left(\frac{\exp \left(X \beta-\alpha_{2}\right)}{\left(1+\exp \left(X \beta-\alpha_{2}\right)\right)^{2}}\right) \beta_{k}
\end{array}\right.
$$

The partial effects on $P(Y=0 \mid X)$ and $P(Y=2 \mid X)$ are unambiguously determined by the sign of $\beta_{k}$, while the sign is not conclusive for the effect on the intermediate category. 
Since partial effects are conditional on specific values for $X$, we follow common practice by setting the variables at their average values. As these partial effects are of little relevance when $X_{k}$ is a dummy variable, we will in these cases rather compute the partial effects for indicator variables as follows:

$$
\partial P(Y=k \mid X) / \Delta X_{k}=P\left(Y=k \mid X_{-k}, X_{k}=1\right)-P\left(Y=k \mid X_{-k}, X_{k}=0\right)
$$

where $X_{-k}$, the explanatory variables other than $X_{k}$, are set at their average values.

\subsubsection{Results}

We report the results of the general and parsimonious ordered Logit model estimations in Table 7. We also report the marginal effects based on the parsimonious model in Table 8.

The estimates of the ordered Logit model confirm the results of the bivariate Logit models on several aspects. First, regarding financial characteristics of the targeted firm, once again we find that variables representing the financial health of the targeted firm are not significant. It means that the financial characteristics of the target firm do not matter in the control decision making-process for GCC SWFs.

Secondly, we find confirmation that GCC SWFs prefer to take the control of a target firm in nations where there are better investment protections. A 0.10 increase in the ANTISELF variable (which stands within the range 0-1), decreases the probability to take a minority stake (less than 10\%) by 4.68 percentage points and increases the probability to take a majority acquisition (more than $50 \%$ ) by 3.59 percentage points, holding all other variables at their means. In the same way, we find that the probability to take a majority (resp. minority) stake increases (resp. decreases) by 21.5 percentage points (resp. 30.5) when the target country is in the European Union.

Thirdly, in line with the results of the bivariate Logit analysis, Table 7 provides evidence against H3 according to which GCC SWFs are more likely to take majority stakes in countries where there are bilateral trade agreements, as both proxies for bilateral trade agreements are non-significant. This result is inconsistent with Johan et al. (2013), Knill et al. (2012) 


\section{Table 7: Ordered Logit models}

This table reports the results of the estimations of the ordered Logit model with robust errors, where the endogenous variable $Y_{i j}$ takes the value 1 if the post-transaction share of the $\mathrm{SWF} i$ in the target $j$ is smaller than $10 \%$, the value 2 if the share lies between $10 \%$ and $50 \%$ and the value 3 if it is larger or equal to $50 \%$. Column (1) reports the estimates for the full model, while column (2) reports the parsimonious model resulting from a backward-selection approach with significance level for removal of the model set at $10 \%$.

\begin{tabular}{|c|c|c|}
\hline TRANSPARENT & $\begin{array}{c}\text { Ologit full } \\
(1) \\
1.298^{* *} \\
(0.625)\end{array}$ & $\begin{array}{c}\text { ologit pars. } \\
(2) \\
1.200^{* *} \\
(0.488)\end{array}$ \\
\hline SUBSIDIARY & $\begin{array}{l}0.283 \\
(0.494)\end{array}$ & \\
\hline EUDUMMY & $\begin{array}{l}0.975 \\
(0.733)\end{array}$ & $\begin{array}{c}1.288^{* * * *} \\
(0.408)\end{array}$ \\
\hline ANTISELF & $\begin{array}{l}2.546^{* *} \\
(1.009)\end{array}$ & $\begin{array}{c}1.971 * * * \\
(0.707)\end{array}$ \\
\hline OILPRICE & $\begin{array}{l}2.102^{*} \\
(1.160)\end{array}$ & $\begin{array}{l}1.903^{*} \\
(1.027)\end{array}$ \\
\hline ROA & $\begin{array}{l}-0.029 \\
(0.032)\end{array}$ & \\
\hline DEBTASSETS & $\begin{array}{l}-1.221 \\
(1.072)\end{array}$ & \\
\hline LIQUIDITY & $\begin{array}{l}0.040 \\
(0.072)\end{array}$ & \\
\hline DEBT & $\begin{array}{c}0.001 \\
(0.008)\end{array}$ & \\
\hline ASSETS & $\begin{array}{l}0.001 \\
(0.003)\end{array}$ & \\
\hline CRISIS & $\begin{array}{l}-0.869^{*} \\
(0.505)\end{array}$ & \\
\hline FTAFORCE & $\begin{array}{c}0.433 \\
(0.711)\end{array}$ & \\
\hline FTANEGO & $\begin{array}{l}-0.291 \\
(0.632)\end{array}$ & \\
\hline dlogREER & $\begin{array}{l}5.280^{*} \\
(2.997)\end{array}$ & \\
\hline GDP & $\begin{array}{l}-0.013 \\
(0.017)\end{array}$ & \\
\hline logKAOPEN & $\begin{array}{l}0.590 \\
(0.718)\end{array}$ & \\
\hline LUXURY & $\begin{array}{l}1.173^{*} \\
(0.652)\end{array}$ & $\begin{array}{l}0.987^{*} \\
(0.538)\end{array}$ \\
\hline FINANCE & $\begin{array}{c}-1.350^{*} \\
(0.799)\end{array}$ & $\begin{array}{c}-1.422^{* *} \\
(0.684)\end{array}$ \\
\hline ENERGY & $\begin{array}{l}-1.109 \\
(0.770)\end{array}$ & $\begin{array}{c}-1.114^{* *} \\
(0.518)\end{array}$ \\
\hline INDUSTRY & $\begin{array}{l}-0.826 \\
(0.826)\end{array}$ & \\
\hline SIZESWF & $\begin{array}{l}-0.002 \\
(0.001)\end{array}$ & \\
\hline POLITY & $\begin{array}{c}0.036 \\
(0.047)\end{array}$ & \\
\hline $\begin{array}{l}\alpha_{1} \\
\alpha_{2}\end{array}$ & $\begin{array}{c}9.757^{*} \\
(5.429) \\
11.543^{* *}\end{array}$ & $\begin{array}{c}9.922^{* *} \\
(4.585) \\
11.532^{* *}\end{array}$ \\
\hline $\begin{array}{l}\text { Log-likelihood } \\
\text { AIC } \\
\text { BIC }\end{array}$ & $\begin{array}{c}-(1.518) \\
213.210 \\
342.420 \\
34.107\end{array}$ & $\begin{array}{c}(4.634) \\
-121.388 \\
260.777 \\
286.159\end{array}$ \\
\hline
\end{tabular}


and Karolyi and Liao (2017) who find that bilateral trade is positively associated with SWF investment, suggesting that variables explaining the investment decision can differ according to the degree of investment acquisition. Our result also indicates that GCC SWFs differ from other institutional investors in their investment strategies as Roque and Cortez (2014) show that bilateral trade significantly contributes to increase institutional investors' international equity investments.

Regarding H4 which posits that GCC SWFs target cross-border companies operating in strategic industries, the estimates of both bivariate Logit models and the ordered Logit model give more contrasted results. In Table 7, the variables FINANCE and ENERGY are negatively significant, which means that the probability of having influential or majority stakes decreases when the target firm belongs to one of these sectors in contrast with minority stakes (less than 10\%). In line with the bivariate Logit model, the variable $L U X U R Y$ is significant in the ordered Logit model, meaning that GCC SWFs do target particularly luxury industry in their takeover decision. These results suggest that cross-border acquisitions taken by GCC SWFs are not a way for these countries to acquire strategic interests abroad. On the other hand, it may be a consequence of the regulations aiming at preventing SWFs

Table 8: Marginal effects at means of the ordered Logit parsimonious model

This table reports for continuous variables the respective marginal effects of ANTISELF and OILPRICE on the probabilities to take minority, influential and majority stakes, all other variables being held constant at their means, and for dichotomous variables the respective marginal effects for an investment of being made in Europe, in the luxury/finance/energy sector and made via a rather transparent SWF, on the probabilities to take minority, influential and majority stakes, all other variables being held constant at their means. The estimates are derived from the benchmark (parsimonious ordered Logit) model reported in column (2) of Table 7 .

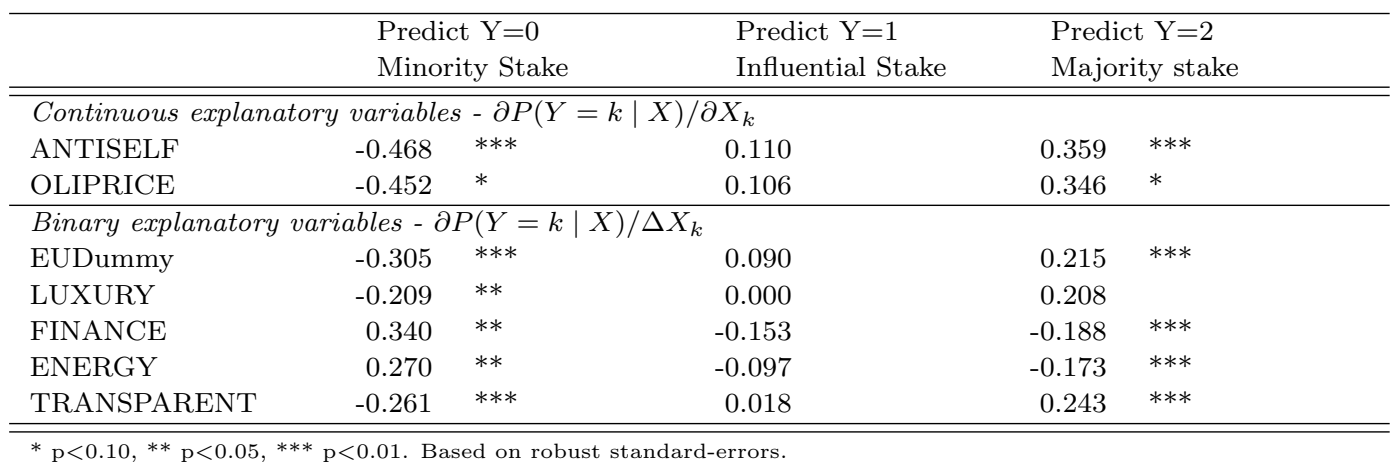


to take significant stakes in strategic sectors. ${ }^{10}$

Not surprisingly, the probability of having influential or majority takeovers increases with the transparency of the fund. When a fund is transparent, the likelihood to take a minority stake decreases by 26.1 percentage points, while the likelihood to take a majority stake (more than $50 \%$ ) increases by 24.3 percentage points. SWFs that are managed in a non-transparent way have a tendency to increase the host country fears. Consequently, transparent SWFs have less trouble taking influential stakes in cross-border companies.

At last, results of the ordered Logit model unsurprisingly confirm that oil trade resources are a driver of GCC SWFs majority acquisitions. GCC SWFs are, indeed, financed by the proceeds from petroleum and gas.

\section{Conclusion}

While there is an extensive literature investigating the SWFs investment decision makingprocess, only few papers address the question of the determinants of SWFs cross-border equity majority acquisitions. This is, however, a key question as it is clear that SWF activism generates more hostility by host-country governments. Understanding the patterns and motivations for SWF cross-border majority acquisition is therefore an important and understudied research topic. Using a unique database of 124 cross-border equity acquisitions from GCC SWFs in 28 target countries over the period 2006-2015, we aim to fill this gap in the literature. Based on ordered Logit models, we test if the usual determinants of SWFs investments stand in the case of majority acquisitions made by a distinct group among SWFs, namely by GCC SWFs.

Unlike results found in the literature investigating the determinants of SWFs cross-border investments, our results indicate that target firm-level characteristics do not matter in the

\footnotetext{
${ }^{10}$ Such regulations are in place in many developed countries such as the United States or the European Union countries.
} 
decision of GCC SWFs cross-border majority acquisition. It means that the financial characteristics of the target firm are not criteria considered in the control decision making-process for GCC SWFs. A major factor determining the pattern of cross-border majority acquisition for this type of investors is the level of shareholder protection in the target country. More precisely, we find that GCC SWFs prefer investing in countries presenting a high level of shareholder protection, preferably in the European Union. In addition, we find that GCC SWFs do not target strategic sectors (except the Luxury sector if we see this sector as strategic) when taking influential or majority stakes, suggesting that cross-border equity majority-border acquisitions are not a way for these countries to acquire strategic interests abroad. The transparency of the fund is also a significant factor determining cross-border majority stake which can be explained by the fact that a transparent SWF likely reduces the hostility and political pressure from the host country's government increasing therefore the probability of influential stake. This result suggests that SWFs wishing to be involved in foreign firms management should improve their degree of transparency. Finally, contrary to the literature on the determinants of cross-border SWFs investments, we do not find some evidence that SWFs prefer to take large or majority acquisitions in countries where there are bilateral agreements. This result indicates that SWFs differ from other institutional investors in their investment strategies.

Overall, our results shed new light on SWFs investment strategy, indicating that even if their objectives may go beyond pure profit maximization, acquiring majority stakes is not a lever for governments to get strategic interests in the targeted country. These results may be of interest for the regulators seeking the optimal regulatory response to the activism of SWFs. 


\section{References}

Al-Hassan A., Papaioannou M., Skancke M., Sung C. C. (2013). Sovereign wealth funds: aspects of governance structures and investment management. IMF Working Paper 231.

Amar, J., B. Candelon, and C. Lecourt (2018). Are sovereign wealth funds decisions based on country factors? Working paper.

Ang, J., A. Knill and N. Mauck (2016). Cross-border opportunity sets: An international empirical study based on ownership types Global Finance Journal.

Avendano, R. (2012). Sovereign wealth fund investments: From firm-level preferences to natural endowments. Working paper, Paris School of Economics.

Avendaño, R. and J. Santiso (2009). Are sovereign wealth funds' investments politically biased? a comparison with mutual funds. OECD Working paper, N. 283.

Ben-Akiva, M. and M. Bierlaire (1999). Discrete choice methods and their applications to short term travel decisions. Handbook of transportation science, 5-33.

Bernstein, S., J. Lerner, , and A. Schoar (2013). The investment strategies of sovereign wealth funds. Journal of Economic Perspectives 27(2), 219-238.

Brant, R. (1990). Assessing proportionality in the proportional odds model for ordinal logistic regression. Biometrics 46(4), 1171-1178.

Carpantier, J.F., and W.N. Vermeulen (2018). Emergence of sovereign wealth funds. Journal of Commodity Markets, forthcoming.

Chhaochharia, V. and L. Laeven (2009). Sovereign wealth funds: their investment strategies and performance. Working paper, International Monetary Fund.

Chinn, M. and H. Ito (2006). What Matters for Financial Development? Capital Controls, Institutions, and Interactions. Journal of Development Economics 81(1), 163-192. 
Ciarlone, A. and Miceli, V. (2016). Escaping financial crisis? Macro-evidence from sovereign wealth fund's investment behaviour. Emerging Markets Review 27, 169-196.

Cohen, B. J. (2009). Sovereign wealth funds and national security: the Great Tradeoff. International Affairs 85(4), 713-731.

Djankov S., La Porta R, Lopez-de-Silanes F. and A. Schleifer (2008). The law and economics of self-dealing. Journal of Financial Economics 88(3), 430-465.

Dyck, A. and A. Morse (2011). Sovereign wealth fund portfolios. MFI Working paper 2011003.

Ederington, L. H. (1985). Classification Models and Bond Ratings. The Financial Review 20(4), 237-262.

Fernandes, N. (2014). The impact of sovereign wealth funds on corporate value and performance. Journal of Applied Corporate Finance 84, 26-76.

Ferreira, M. A. and P. Matos (2008). The color of investors' money: The role of institutional investors around the world. Journal of Financial Economics 88(3), 499-533.

Greene, E. and B. Yeager (2008). Sovereign wealth funds: a measured assessment. Capital Markets Law Journal, 3(3), 247-274.

Hay F. and C. Milelli (2014). The increasing interest of Middle Eastern sovereign wealth funds for Europe: presenting original data. Working Paper. Economix 2014-38.

Heaney, R., Li, R. and V. Valencia (2011). Sovereign wealth fund investment decisions: Temasek holdings. Australian Journal of Management 36, 109-120.

Hoeckman, B. M. and M. M. Kostecki (2009). The political economy of the world trading system: from GATT to WTO. Oxford University Press, 301 pages.

IMF (2004). Sovereign wealth funds: a work agenda. IMF. 
Johan A., Knill, A., B., and N. Mauck (2013). Determinants of Sovereign Wealth Fund Investment in Private versus Public Equity. Journal of International Business Studies 44 , (2), 155-172.

Karolyi, G. and R. C. Liao (2017). State capitalism's global reach: Evidence from foreign acquisitions by state-owned companies. Journal of Corporate Finance 42, 367-391.

Knill, A., B.-S. Lee, and N. Mauck (2012). Bilateral political relations and sovereign wealth fund investment. Journal of Corporate Finance 18(1), 108-123.

Kotter, J. and U. Lel (2011). Friends or foes? Target selection decisions of sovereign wealth funds and their consequences. Journal of Financial Economics 101, 360-381.

Long, J. S. and J. Freese (2014). Regression models for categorical dependent variables using stata (3rd ed.). College Station TX: Stata Press.

Megginson, W.L, You, M. and L. Han (2013). Determinants of sovereign wealth fund crossborder investments. The Financial Review, 148, 539-572.

Murtinu, S. and V. G. Scalera (2016). Sovereign Wealth Funds' Internationalization Strategies: The Use of Investment Vehicles. Journal of International Management 22, (3), 249-264.

Poon, W. P. H. (2003). Are unsolicited credit ratings biased downward? Journal of Banking and Finance 27(4), 593-614.

Roque V. and M. C. Cortez (2014). The determinants of international equity investment: Do they differ between institutional and noninstitutional investors? Journal of Banking and Finance, $49(\mathrm{C}), 469-482$.

Sachs, J. D. and A. M. Warner (1995). Natural resource abundance and economic growth. NBER Working Paper, 5398. 
Sachs, J. D. and A. M. Warner (2001). The curse of natural resources. European Economic Review 45, 827-838.

Sala-i-Martin, X. and A. Subramanian (2003). Addressing the natural resource curse: an illustration from Nigeria. IMF Working Paper 03/139.

Seznec, J-F. (2008). The Gulf sovereign wealth funds: myths and reality. Middle East Policy, $97-110$.

Smith, B. (2004). Oil wealth and regime survival in the developing world, 1960-1999. American Journal of Political Science 48, (2), 232-246.

Sturm, M., Strasky, J., Adolf, P. and D., Peschel (2008) The Gulf Cooperation Council Countries. Economic structures, recent developments and role in the global economy. ECB Occasional Paper Series 92.

Train, K. (2003). Discrete Choice Methods with Simulation. Cambridge University Press, pp. 334 .

Wooldridge, J.M. (2010). Econometrics of cross section and panel data. The MIT Press, pp. 1044. 